\title{
Mycoplasma simbae sp. nov., Mycoplasma leopharyngis sp. nov., and Mycoplasma leocaptivus sp. nov., Isolated from Lions
}

\author{
AURIOL C. HILL \\ Medical Research Council Toxicology Unit, Woodmansterne Road, \\ Carshalton, Surrey SMS 4EF, United Kingdom
}

\begin{abstract}
Mycoplasmas isolated from the throats of lions were shown to belong to three serotypes, all of which were serologically distinct from the previously recognized Mycoplasma and Acholeplasma spp. Eight mycoplasma colonies were cloned, including one from a leopard (strain LP), and were examined in detail for morphology, growth, and biochemical characteristics. The strains had the following properties: guanine-plus-cytosine contents of 37 mol\% (strain $L X^{T}\left[T=\right.$ type strain]), 28 mol\% (strain $L L 2^{T}$ ), and 27 mol\% (strain $3 L_{2}{ }^{T}$ ) and a requirement for sterol. Strain $3 \mathrm{L2}^{\mathrm{T}}$ metabolized glucose, which was not metabolized by strains $\mathrm{LX}^{\mathrm{T}}$ and $L_{2}{ }^{T}$. Arginine and urea were not hydrolyzed. Strain LX (= NCTC 11724) is the type strain of a new species, Mycoplasma simbae; strain LL2 (= NCTC 11725) is the type strain of a second new species, Mycoplasma leopharyngis; and strain 3L2 (= NCTC 11726) is the type strain of a third new species, Mycoplasma leocaptivus.
\end{abstract}

There have been few reports of isolation of mycoplasmas from large feline animals $(11,12,16,32)$. Mycoplasma arginini has been recovered from a variety of hosts, including lions $(12,32)$. Also, there have been reports of some glucose-metabolizing isolates that were obtained from large felines and exhibited a biochemical and/or serological relationship to Mycoplasma felis $(12,16)$. Other isolates could not be identified as previously described species in the class Mollicutes and have been subjected to further taxonomic study.

In this paper I describe the characterization of three mycoplasma serotypes from lions (Pantherae leo) and propose that these mycoplasmas should be classified as three new Mycoplasma species.

\section{MATERIALS AND METHODS}

Mycoplasma strains. Mycoplasmas were isolated from the throats of captive lions and a leopard; these animals were kept at the Zoological Society of London in Regents Park and Longleat Safari Park in the United Kingdom. Swabs taken from a throat were rubbed over the surface of an agar culture medium and were inoculated into broth media containing glucose and arginine $(13,29)$. The inoculated liquid media were diluted $1 / 10$. One colony isolated from each animal was cloned to produce a pure culture; this was done by initially filtering a broth culture through a 220 -nm-poresize membrane, culturing the filtrate on solid medium, transferring a single resulting colony to another agar plate, and inoculating the subsequent growth into broth. This whole procedure was repeated an additional four times; thus, the organisms were filter-cloned five times (27). The clones were designated strains $\mathrm{LX}^{\mathrm{T}}$ ( $\mathrm{T}=$ type strain), $\mathrm{LL} 1, \mathrm{LX} 3, \mathrm{LL}^{\mathrm{T}}$, $\mathbf{L X} 1,3 \mathrm{~L} 2^{\mathrm{T}}, \mathbf{L A}$, and LP (strain LP was isolated from a leopard).

Mycoplasma species. Mycoplasma type strains were obtained from the National Collection of Type Cultures, Colindale, England, and from H. Atobe, M. F. Barile, J. M. Bradbury, R. H. Fallon, E. A. Freundt, J. T. Heywood, F. T. W. Jordan, D. E. Jasper, H. Kirchhoff, R. H. Leach, G. J. McGarrity, D. L. Rose, G. Smith, D. Taylor-Robinson, and J. G. Tully.

The following Mycoplasma spp. type strains were used: M. agalactiae PG2, M. alkalescens D12 (= PG51), M. alvi
Ilsley, $M$. anatis $1340, M$. anseris $1219, M$. arginini $\mathrm{G} 230$, M. arthritidis PG6, M. bovigenitalium PG11, M. bovirhinis PG43, M. bovis PG45, M. bovoculi M165/69, M. buccale CH-20247, $M$. californicum ST-6, $M$. canadense 275C, $M$. canis $\mathrm{PG} 14, M$. capricolum California kid, $M$. caviae G122, $M$. cavipharyngis $117 \mathrm{C}, M$. citelli $\mathrm{RG}-2 \mathrm{C}, M$. cloacale 383 , $M$. collis $58 \mathrm{~B}, M$. columbinasale $694, M$. columbinum MMP1, $M$. columborale MMP4, $M$. conjunctivae HRC581, $M$. cricetuli $\mathrm{CH}, M$. cynos H831, $M$. dispar 462/2, $M$. edwardii PG24, M. ellychniae ELCN-1, M. equigenitalium T37, $M$. equirhinis M432/72, $M$. fastidiosum 4822, $M$. faucium DC333, $M$. felifaucium PU, $M$. feliminutum Ben, $M$. felis CO, $M$. fermentans PG18, $M$. flocculare MS42, $M$. gallinaceum DO, M. gallinarum PG16, M. gallisepticum PG31, M. gallopavonis WR1, M. gateae CS, M. genitalium G-37, M. glycophilum 486, $M$. hominis PG21, $M$. hyopharyngis H3-6BF, $M$. hyopneumoniae J, $M$. hyorhinis BTS7, $M$. hyosynoviae S16, M. iners PG30, $M$. iowae $695, M$. lactucae 831-C4, M. lipofaciens R171, $M$. lipophilum MaBy, $M$. luminosum PIMN-1, $M$. lucivorax PIPN-2, M. maculosum $\mathrm{PG} 15, M$. melaleucae $\mathrm{M1}, M$. meleagridis $17529, M$. moatsii MK405, $M$. mobile 163K, $M$. molare H542, $M$. muris RIII4, $M$. mustelae $\mathrm{MX9}, M$. mycoides subsp. capri PG3, $M$. mycoides subsp. mycoides PG1, $M$. neurolyticum Type A, M. opalescens MH5408, M. orale CH-19299, M. ovipneumoniae Y98, M. oxoniensis 128, M. phocacerebrale 1049, $M$. phocarhinis $852, M$. pirum HRC70-159, $M$. pneumoniae FH, $M$. primatum HRC292, $M$. pullorum CKK, M. pulmonis PG34 (= ASH), $M$. putrefaciens KS-1, $M$. salivarium PG20, $M$. somnilux PYAN-1, $M$. spermatophilum AH159, $M$. spumans PG13, $M$. sualvi Mayfield (clone B), $M$. subdolum TB, $M$. synoviae WVU1853, $M$. testudinis 01008 , and $M$. verecundum 107.

The following Acholeplasma spp. type strains were used: $A$. axanthum S743, $A$. entomophilum TAC, $A$. equifetale N93, $A$. florum LI, $A$. granularum BTS39, $A$. hippikon $\mathrm{C} 1$, A. laidlawii PG8, $A$. modicum PG49, $A$. morum 72-043, $A$. multilocale PN525, $A$. oculi 19L, and $A$. parvum H23M.

Medium and growth conditions. The culture medium which I used has been described previously $(13,29)$. The purified agar used in the growth medium was either Ionagar no. 2 (Oxoid, Ltd., Basingstoke, England) or Lab M agar (Lab M, London, England). Depending on their biochemical activities, the mycoplasmas were grown in liquid medium contain- 


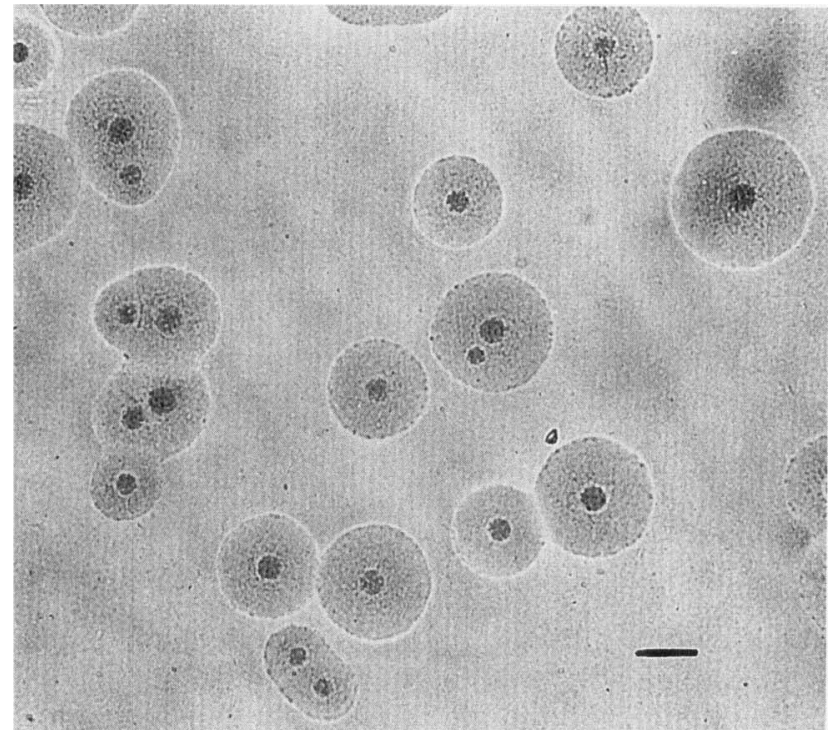

FIG. 1. Colonies of strain $\mathrm{LX}^{\mathrm{T}}$ grown under aerobic conditions for 2 days on an agar medium. Bar $=100 \mu \mathrm{m}$.

ing $1 \%(\mathrm{wt} / \mathrm{vol})$ glucose ( $\mathrm{pH} 7.8)$ or in liquid medium containing 0.5 to $1 \%$ (wt/vol) arginine ( $\mathrm{pH} 7.3$ ). The species grew in medium containing $1 \%$ arginine and were not inhibited. Agar cultures were incubated at 35 to $37^{\circ} \mathrm{C}$ either in a humid chamber or under anaerobic conditions by using a GasPak system (B.D. UK Ltd., Cowley, Oxford, England). Liquid cultures were stored at $-70^{\circ} \mathrm{C}$ in ampoules.

Tests to determine the following characteristics were carried out as described in an accompanying paper (14a): growth requirements and characteristics (7), absence of reversion $(30)$, morphology $(8,15,34)$, filtration characteristics, sterol dependence $(5,6,24,33)$, biochemical activity $(1$, $2,17,26,31,35)$, erythrocyte hemolysis and agglutination $(1$, 18), polyacrylamide gel electrophoresis behavior (20), DNA base composition $(10,25)$, and serological characteristics $(4$, $13,14,19,21-23,26)$.

The clones were tested indirectly for sterol dependence by a paper disk inhibition method (9), using either dried disks that originally contained $0.02 \mathrm{ml}$ of a $1.5 \%$ (wt/vol) ethanolic solution of digitonin (Sigma Chemical Co., St. Louis, Mo.) or wet disks that contained $0.02 \mathrm{ml}$ of a $20 \%$ (wt/vol) aqueous solution of sodium polyanethol sulfonate (Koch-Light Laboratories, Ltd., Colnbrook, England) on basal growth medium containing Lab $\mathrm{M}$ agar. The widths of zones of growth inhibition were measured.

\section{RESULTS AND DISCUSSION}

The serological techniques which I used revealed similar levels of cross-reactions among strains $\mathrm{LX}^{\mathrm{T}}, \mathrm{LL1}$, and $\mathrm{LX} 3$, between strains $\mathrm{LL} 2^{\mathrm{T}}$ and $\mathrm{LX} 1$, and among strains $3 \mathrm{~L} 2^{\mathrm{T}}$, LA, and LP. No significant cross-reactions were detected with any of the species listed in Materials and Methods or when the three separate species (type strains LX, LL2, and 3L2) were tested against each other.

Colonies of all of the strains were visible in subcultures after 2 days of incubation on agar medium $(13,29)$ under aerobic and anaerobic conditions. The colonies (Fig. 1

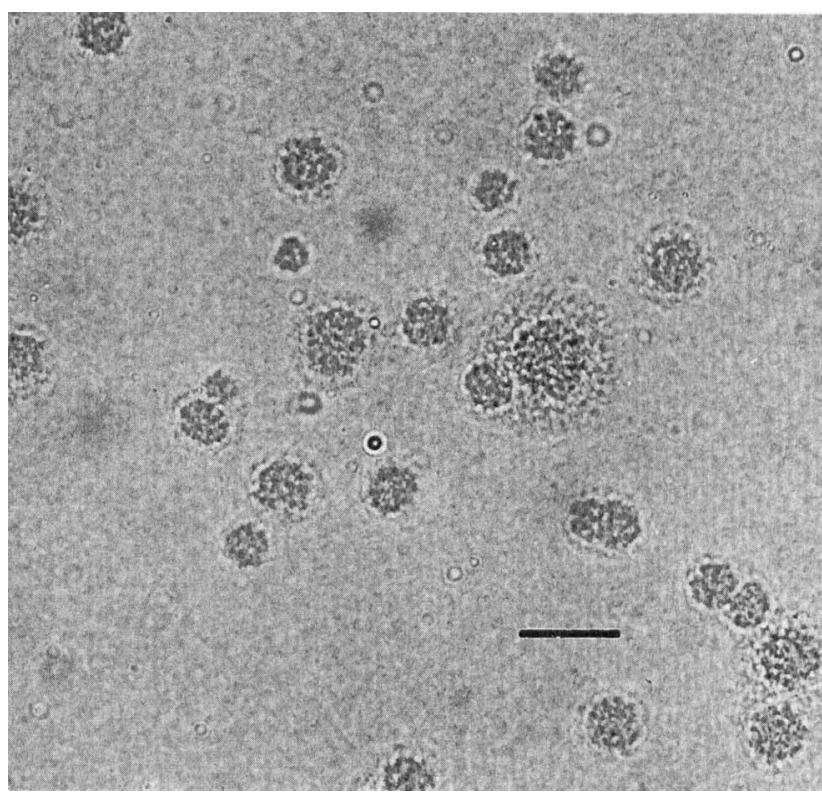

FIG. 2. Colonies of strain LL2 ${ }^{\mathrm{T}}$ grown under aerobic conditions for 2 days on an agar medium. Bar $=50 \mu \mathrm{m}$.

through 3) had a typical fried-egg appearance. The growth characteristics are summarized in the species descriptions below. The strains did not revert to bacterial forms when the organisms were subcultured on a medium without bacterial inhibitors. The colonies rapidly stained with Dienes reagent, confirming that the isolates were true mycoplasmas (members of the Mollicutes) rather than bacterial L-forms (30).

No motility was observed in fluid medium when the strains were examined by dark-field microscopy, and helical forms were not seen. Preparations from liquid cultures stained with Giemsa stain contained pleomorphic forms characteristic of mycoplasmas. The ultrastructure of the strains was typical

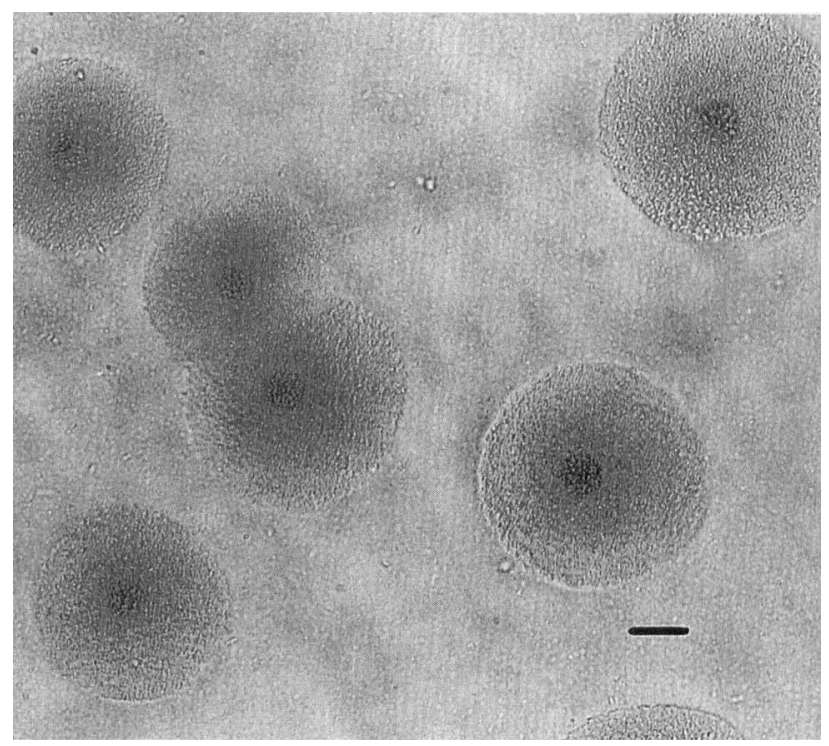

FIG. 3. Colonies of strain $3 \mathrm{~L}^{\mathrm{T}}$ grown under aerobic conditions for 2 days on an agar medium. Bar $=100 \mu \mathrm{m}$. 


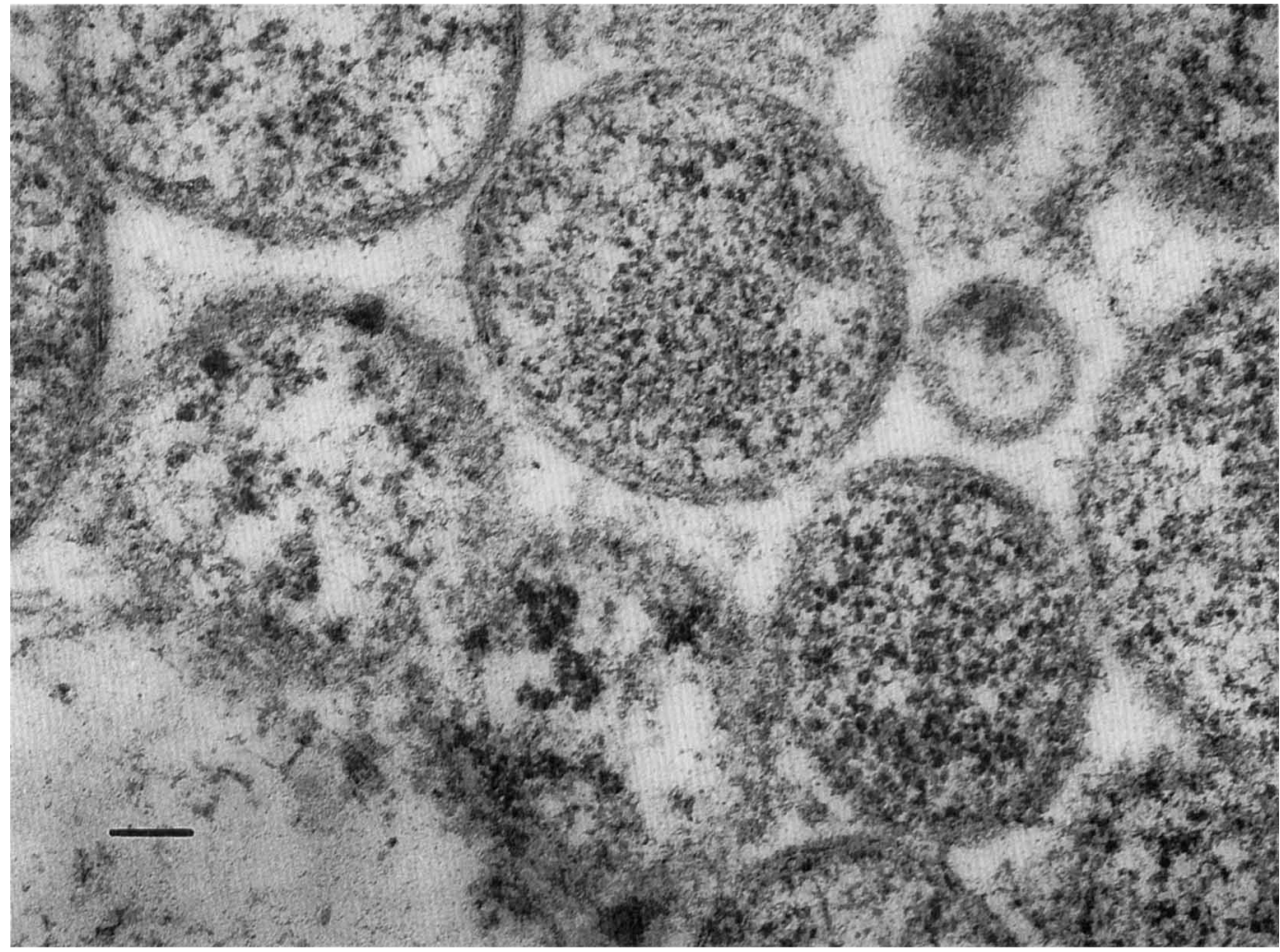

FIG. 4. Electron micrograph of a section of strain $\mathbf{L X}^{\mathrm{T}}$ cells stained with uranyl acetate and lead citrate. Bar $=200 \mathrm{~nm}$.

of mycoplasma morphology when thin sections were viewed by electron microscopy (3). The cells were bounded by a trilaminar unit membrane and lacked any evidence of cell wall material (Fig. 4 through 6).

Filtration of strain $\mathrm{LX}^{\mathrm{T}}$ through a 220 -nm-pore-size membrane reduced the titer from $8.0 \times 10^{7}$ to $2 \times 10^{4} \mathrm{CFU} / \mathrm{ml}$. Filtration of strain $\mathrm{LL} 2^{\mathrm{T}}$ through a $220-\mathrm{nm}$-pore-size membrane reduced the titer from $1.0 \times 10^{7}$ to $2.0 \times 10^{3} \mathrm{CFU} / \mathrm{ml}$. Filtration of strain $3 \mathrm{~L} 2^{\mathrm{T}}$ through a 220 -nm-pore-size membrane reduced the titer from $2.0 \times 10^{8}$ to $5.0 \times 10^{3} \mathrm{CFU} / \mathrm{ml}$.

All of the strains required cholesterol for growth. They could not be cultured on medium without cholesterol, but they grew and were passaged on medium containing $10 \mu \mathrm{g}$ of cholesterol per ml for strain $\mathrm{LX}^{\mathrm{T}}$ and $1 \mu \mathrm{g}$ of cholesterol per $\mathrm{ml}$ for strains $\mathrm{LL} 2^{\mathrm{T}}$ and $3 \mathrm{~L} 2^{\mathrm{T}}$. The strains were susceptible to digitonin and sodium polyanethol sulfonate, and the zones of growth inhibition were 8 and $6 \mathrm{~mm}$ wide, respectively, for strain $\mathrm{LX}^{\mathrm{T}}, 6$ and $4 \mathrm{~mm}$ wide, respectively, for strain $\mathrm{LL}^{\mathrm{T}}$, and 8 and $7 \mathrm{~mm}$ wide, respectively, for strain $3 \mathrm{~L} 2^{\mathrm{T}}$; under these conditions growth was semiconfluent.

The biochemical activities of the strains are summarized in the species descriptions below. In appropriate tests all of the strains were hemolytic for chick, guinea pig, and sheep erythrocytes. Strain $\mathbf{L X}^{\mathrm{T}}$ both adsorbed and agglutinated all of the cells, but strains $\mathrm{LL} 2^{\mathrm{T}}$ and $3 \mathrm{~L} 2^{\mathrm{T}}$ did not adsorb or agglutinate the cells.

The guanine-plus-cytosine contents of the DNAs of the species described in this paper were determined from their buoyant densities in cesium chloride to be $37 \mathrm{~mol} \%$ (strain $\mathrm{LX}^{\mathrm{T}}$ ), $28 \mathrm{~mol} \%$ (strain $\mathrm{LL} 2^{\mathrm{T}}$ ), and $27 \mathrm{~mol} \%$ (strain $3 \mathrm{~L} 2^{\mathrm{T}}$ ). These values are within the range of values obtained for previously characterized Mycoplasma species.
Similar electrophoretic patterns were obtained for strains $\mathrm{LX}^{\mathrm{T}}, \mathrm{LL1}$, and $\mathrm{LX} 3$ and for strains $\mathrm{LL} 2^{\mathrm{T}}$ and $\mathrm{LX} 1$.

Strains $\mathrm{LX}^{\mathrm{T}}, \mathrm{LL} 2^{\mathrm{T}}$, and $\mathrm{LX} 3^{\mathrm{T}}$ belong to the family $M y$ coplasmataceae on the basis of their main characteristics, including absence of cell walls, lack of reversion to bacterial L-forms when the organisms are grown in antibiotic-free media, penicillin resistance, filterability, and production of typical morphology on agar. They belong to the genus Mycoplasma because they are not strict anaerobes (in contrast to Anaeroplasma spp.), because they are nonhelical (in contrast to Spiroplasma spp.), because they depend on sterol for growth (in contrast to Acholeplasma spp.), and because urease activity could not be demonstrated (in contrast to Ureapleasma spp.).

Strains $\mathrm{LX}^{\mathrm{T}}, \mathrm{LL} 1$, and $\mathrm{LX} 3$ belong to the same species because they have similar biological characteristics, produce similar protein patterns, and exhibit serological identity. Similarly, strains $\mathrm{LL} 2^{\mathrm{T}}$ and $\mathrm{LX} 1$ belong to the same species, and strains $3 \mathrm{~L} 2^{\mathrm{T}}, \mathrm{LA}$, and LP belong to a third species. As there were no significant cross-reactions with any of the previously recognized Mycoplasma spp. (listed in Materials and Methods), strains $\mathrm{LX}^{\mathrm{T}}, \mathrm{LL} 2^{\mathrm{T}}$, and $3 \mathrm{~L} 2^{\mathrm{T}}$ belong to three new Mycoplasma species.

Description of Mycoplasma simbae sp. nov. Mycoplasma simbae (sim'bae. L.n. simba, lion; L. gen. n. simbae, of a lion [in Swahili]).

Morphological and physical characteristics. Pleomorphic cells are bounded by a single unit membrane. Colonies have a typical fried-egg appearance on agar. Organisms are filterable through 220 -nm-pore-size membrane filters and are resistant to penicillin.

Growth characteristics. Requires sterol; inhibited by digi- 


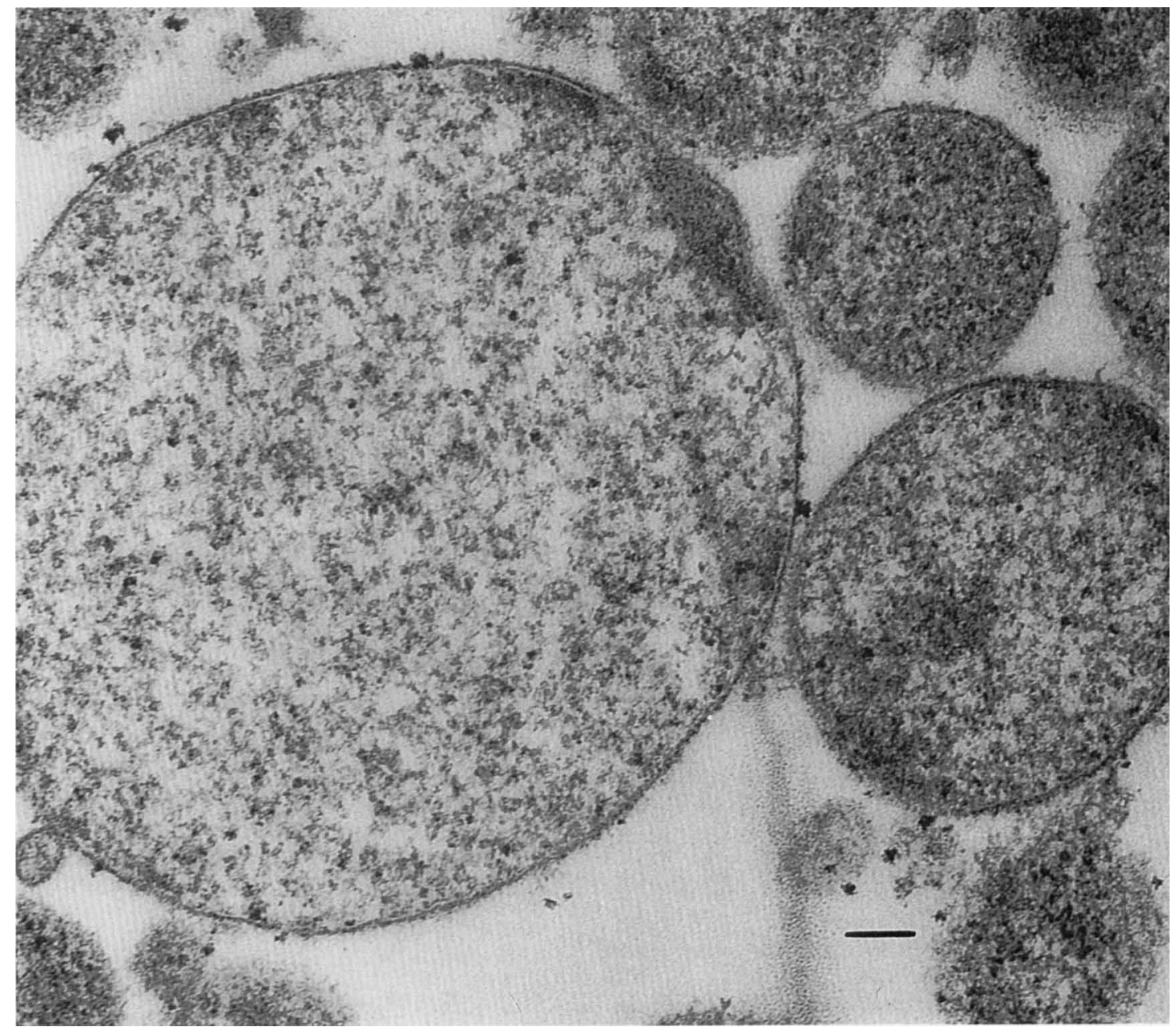

FIG. 5. Electron micrograph of a section of strain $\mathrm{LL}^{\mathrm{T}}$ cells stained with uranyl acetate and lead citrate. Bar $=200 \mathrm{~nm}$.

tonin and sodium polyanethol sulfonate. Optimal growth occurs at 35 to $37^{\circ} \mathrm{C}$ under both aerobic and anaerobic conditions. A film is produced on egg yolk agar. Growth is not inhibited by $0.002 \%$ methylene blue in agar.

Metabolic characteristics. No carbohydrates are metabolized; arginine, esculin, and urea are not hydrolyzed; methylene blue, resazurin, tellurite, and tetrazolium are reduced; phosphatase is produced.

Serological characteristics. Serologically distinct from all other Mycoplasma species.

DNA base composition. The DNA base composition is 37 mol\% guanine-plus-cytosine.

Habitat. The habitat is lion throats.

Type strain. The type strain is strain LX (= NCTC 11724).

Description of Mycoplasma leopharyngis sp. nov. Mycoplasma leopharyngis (le.o.phar.yn'gis. L.n. leo, lion; L.n. pharynx, throat; L.n. leopharyngis, pharynx of a lion).

Morphological and physical characteristics. Pleomorphic cells are bounded by a single unit membrane. Colonies have a typical fried-egg appearance on agar. Organisms are filterable through 220-nm-pore-size membrane filters and are resistant to penicillin.

Growth characteristics. Requires sterol; inhibited by digitonin and sodium polyanethol sulfonate. Optimal growth occurs at 35 to $37^{\circ} \mathrm{C}$ under both aerobic and anaerobic conditions. A film is produced on egg yolk agar, and lipolytic activity occurs. Growth is not inhibited by $0.002 \%$ methylene blue in agar.

Metabolic characteristics. No carbohydrates are metabolized; arginine, esculin, and urease are not hydrolyzed; resazurin and tellurite (under anaerobic conditions) are reduced, but methylene blue and tetrazolium are not reduced; phosphatase is produced.

Serological characteristics. Serologically distinct from all other Mycoplasma species.

DNA base composition. The DNA base composition is 28 mol\% guanine-plus-cytosine.

Habitat. The habitat is lion throats.

Type strain. The type strain is strain LL2 (= NCTC 11725).

Description of Mycoplasma leocaptivus sp. nov. Mycoplasma leocaptivus (le.o.cap'ti.vus. L.n. leo, lion; L. adj. captivus, captive; M.L. adj. leocaptivus, captive lion).

Morphological and physical characteristics. Pleomorphic cells are bounded by a single unit membrane. Colonies have a typical fried-egg appearance on agar. Organisms are filterable through 220-nm-pore-size membrane filters and are resistant to penicillin. 


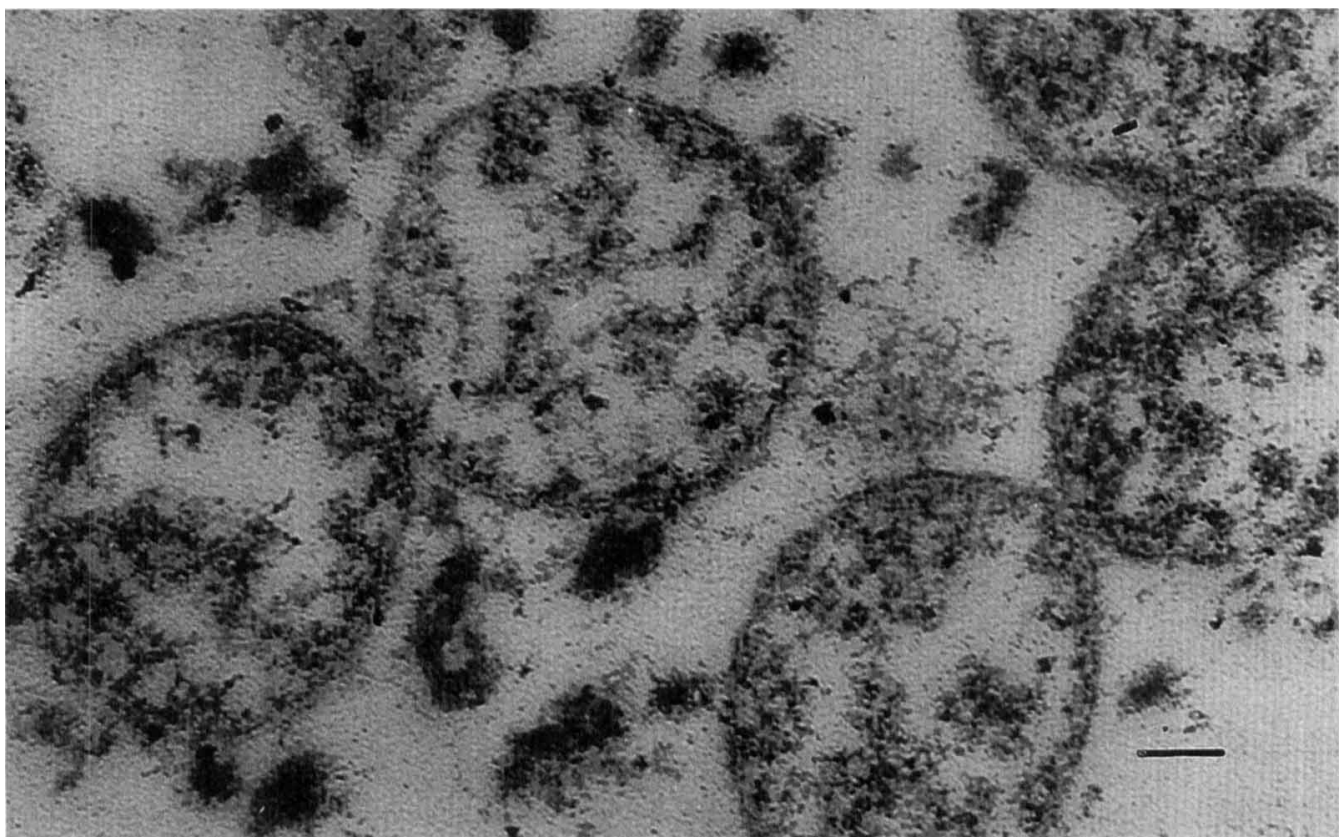

FIG. 6. Electron micrograph of a section of strain $3 \mathrm{~L} 2^{\mathrm{T}}$ cells stained with uranyl acetate and lead citrate. Bar $=200 \mathrm{~nm}$.

Growth characteristics. Requires sterol; inhibited by digitonin and sodium polyanethol sulfonate. Optimal growth occurs at 35 to $37^{\circ} \mathrm{C}$ under aerobic and anaerobic conditions. A film is produced on egg yolk agar, and lipolytic activity occurs. Growth is inhibited by $0.002 \%$ methylene blue in agar.

Metabolic characteristics. Glucose, maltose, mannose, raffinose, and sucrose are metabolized; arginine, esculin, and urea are not hydrolyzed; resazurin and tellurite (under anaerobic conditions) are reduced, but methylene blue and tetrazolium are not reduced; phosphatase is produced.

Serological characteristics. Serologically distinct from all other Mycoplasma species.

DNA base composition. The DNA base composition is 27 mol\% guanine-plus-cytosine.

Habitat. The habitat is lion and leopard throats.

Type strain. The type strain is strain $3 \mathrm{~L} 2$ (= NCTC 11726).

\section{ACKNOWLEDGMENT}

I thank G. A. Stalley for performing the DNA base composition and electrophoresis tests and J. G. Tully and D. Rose for some comparative serology.

\section{REFERENCES}

1. Aluotto, B. B., R. G. Wittler, C. O. Williams, and J. E. Faber. 1970. Standardized bacteriologic techniques for the characterization of Mycoplasma species. Int. J. Syst. Bacteriol. 20:35-58.

2. Barber, T. L., and J. Fabricant. 1971. Identification of $\mathrm{Myco}$ plasmatales: characterization procedures. Appl. Microbiol. 21: $600-605$.

3. Boatman, E. S. 1979. Morphology and ultrastructure of the Mycoplasmatales, p. 63-102. In M. F. Barile and S. Razin (ed.), The mycoplasmas, vol. 1. Academic Press, Inc., New York.

4. Clyde, W. A., Jr. 1964. Mycoplasma species identification based upon growth inhibition by specific antisera. J. Immunol. 92:958-965.

5. Edward, D. G. ff. 1971. Determination of sterol requirement for Mycoplasmatales. J. Gen. Microbiol. 69:205-210.

6. Edward, D. G. ff., and W. A. Fitzgerald. 1951. Cholesterol in the growth of organisms of the pleuropneumonia group. J. Gen.
Microbiol. 5:576-586.

7. Fabricant, J., and E. A. Freundt. 1967. Importance of extension and standardization of laboratory tests for the identification and classification of mycoplasma. Ann. N.Y. Acad. Sci. 143:50-58.

8. Fallon, R. J., and P. Whittlestone. 1969. Isolation, cultivation and maintenance of mycoplasmas. Methods Microbiol. 3B:211267.

9. Freundt, E. A., B. E. Andrews, H. Erno, M. Kunze, and F. T. Black. 1973. The sensitivity of Mycoplasmatales to sodiumpolyanethol sulfonate and digitonin. Zentralbl. Bakteriol. Parasitenkd. Infektionskr. Hyg. Abt. 1 Orig. Reihe A 225:104-112.

10. Gross-Bellard, M. J., P. Oudet, and P. Chambon. 1973. Isolation of high molecular weight DNA from mammalian cells. Eur. J. Biochem. 36:32-38.

11. Hill, A. 1972. The isolation of Mycoplasma arginini from captive wild cats. Vet. Rec. 91:224-225.

12. Hill, A. 1975. Comparison of mycoplasmas isolated from captive wild felines. Res. Vet. Sci. 18:139-143.

13. Hill, A. C. 1971. Mycoplasma caviae, a new species. J. Gen. Microbiol. 65:109-113.

14. Hill, A. C. 1977. The metabolic inhibition test for mycoplasmas based on phosphatase production. J. Hyg. 79:391-393.

14a.Hill, A. C., A. A. Polak-Vogelzang, and A. F. Angulo. 1992. Acholeplasma multilocale sp. nov., isolated from a horse and a rabbit. Int. J. Syst. Bacteriol. 42:513-517.

15. Klieneberger-Nobel, E. 1962. Morphology of pleuropneumonialike organisms, p. 23-56. In E. Klieneberger-Nobel (ed.), Pleuropneumonia-like organisms (PPLO): Mycoplasmataceae. Academic Press, Inc., New York.

16. Koshimizu, K., H. Kotani, M. Ito, K. Tashiro, M. Masui, K. Tanabe, I. Kawasaki, K. Saito, and H. Hiramatsu. 1984. Further isolation of mycoplasmas from zoo-animals. Jpn. J. Vet. Sci. 46:129-132.

17. Leach, R. H. 1976. The inhibitory effect of arginine on growth of some mycoplasmas. J. Appl. Bacteriol. 41:259-264.

18. Manchee, R. J., and D. Taylor-Robinson. 1968. Hemadsorption and hemagglutination by mycoplasmas. J. Gen. Microbiol. 50:465-478.

19. Morton, H. E., and R. J. Roberts. 1967. Production of antimycoplasma (PPLO) antibodies in rabbits. Proc. Soc. Exp. Biol. Med. 125:538-543.

20. Mouches, C., and J. M. Bové. 1983. Electrophoretic character- 
ization of mycoplasma proteins. Methods Mycoplasmol. 1:241255.

21. Polak-Vogelzang, A. A., R. Hagenaars, and S. Nagel. 1978. Evaluation of an indirect immunoperoxidase test for identification of Acholeplasma and Mycoplasma. J. Gen. Microbiol. 106:241-249.

22. Purcell, R. H., D. Taylor-Robinson, D. C. Wong, and R. M. Chanock. 1966. A color test for the measurement of antibody to the non-acid-forming human mycoplasma species. Am. J. Epidemiol. 84:51-66.

23. Purcell, R. H., D. Taylor-Robinson, D. C. Wong, and R. M. Chanock. 1966. Color test for the measurement of antibody to T-strain mycoplasmas. J. Bacteriol. 92:6-12.

24. Razin, S., and J. G. Tully. 1970. Cholesterol requirement of mycoplasmas. J. Bacteriol. 102:306-310.

25. Schildkraut, C. L., J. Marmur, and P. Doty. 1962. Determination of the base composition of deoxyribonucleic acid from its buoyant density in CsCl. J. Mol. Biol. 4:430-443.

26. Shepard, M. C., and D. R. Howard. 1970. Identification of " $T$ " mycoplasmas in primary agar cultures by means of a direct test for urease. Ann. N.Y. Acad. Sci. 174:809-819.

27. Subcommittee on the Taxonomy of Mollicutes. 1979. Proposal of minimal standards for description of new species of the class Mollicutes. Int. J. Syst. Bacteriol. 29:172-180.
28. Taylor-Robinson, D., R. H. Purcell, D. C. Wong, and R. M. Chanock. 1966. A color test for the measurement of antibody to certain mycoplasma species based upon the inhibition of acid production. J. Hyg. 64:91-104.

29. Taylor-Robinson, D., M. H. Williams, and D. A. Haig. 1968. The isolation and comparative biological and physical characteristics of T-mycoplasmas of cattle. J. Gen. Microbiol. 54:33-46.

30. Timms, L. 1967. Isolation and identification of avian mycoplasmas. J. Med. Lab. Technol. 24:79-89.

31. Tully, J. G. 1965. Biochemical, morphological and serological characterization of mycoplasma of murine origin. J. Infect. Dis. 115:171-185.

32. Tully, J. G., R. A. Del Giudice, and M. F. Barile. 1972. Synonymy of Mycoplasma arginini with Mycoplasma leonis. Int. J. Syst. Bacteriol. 22:47-49.

33. Tully, J. G., and S. Razin. 1969. Characteristics of a new sterol non-requiring mycoplasma. J. Bacteriol. 98:970-978.

34. Venable, J. H., and R. Coggeshall. 1965. A simplified lead citrate stain for use in electron microscopy. J. Cell Biol. 25:407.

35. Williams, C. O., and R. G. Wittler. 1971. Hydrolysis of esculin and phosphatase production by members of the order $\mathrm{Myco}-$ plasmatales which do not require sterol. Int. J. Syst. Bacteriol. 21:73-77. 